DOI https://doi.org/10.36059/978-966-397-196-4/81-105

\title{
SYNCRETIC CONSTRUCTIONS WITH SIGNS OFCOMPLEX SENTENCES IN MODERN UKRAINIAN
}

\section{Khrystianinova R. O.}

\section{INTRODUCTION}

Not all language units have a distinct discretion; some of them have a syncretic (undivided, intermediate, transitional, double, triple) nature, they are inherent syncretism ${ }^{1}$. The main reason giving rise to syncretic units is transitivity ${ }^{2}$. Transitivity often occurs when a language unit is used in a non-typical function. Syntactic syncretism in most cases is interpreted as combining features of two or more syntactic units in one syntactic unit ${ }^{3}$.

The study of complex sentences in various aspects allows us to determine their typical, symmetrical and asymmetrical expressions. As mentioned above, complex subordinate sentences generally appear as structures that are both, formally and syntactically, distinguished by a unidirectional subordinate relationship between syntactically unequal predicative parts - principal and subordinate. The main means of expression of this link are conjunctions and connective words. Semanticsyntactic relations inherent in complex sentences are based mainly on the semantics of the dependent component. The direct means of expressing these relations are also conjunctions and connective words. The relationship that emerges from the communication tool is the semantics of the structural scheme. However, the fact is that in real sentences the lexico-semantic execution of the predicative parts may or may not support the semantics of the structural scheme. Consequently, in the first case, there is a symmetrical matching of the semantics of the structural

1 Загнітко А. П. Теорія сучасного синтаксису. Донецьк : ДонНУ, 2007. C. 242 .

2 Бабайцева В. В. Явления переходности в грамматике русского языка. Москва: Дрофа, 2000. С. 234; Балли Ш. Общая лингвистика и вопросы французского языка / пер. с фр. Е. В. и Т. В. Вентцель. Москва : УРСС, 2001. C. 81 .

3 Загнітко А. П. Теорія сучасного синтаксису. Донецьк : ДонНУ, 2007. C. 242 . 
scheme to the semantics of the specific speech representation of this scheme; this is the way typical semantic manifestations of complex sentences are formed:

In the second case, the atypical lexical-semantic design causes a mismatch between the semantics of the structural scheme and the content of its specific speech expression, which makes the structural scheme's semantics complicated by other types of meaningful relations, that is, syncretic constructions occur: the meaning of purpose is combined with the causal one.

Many syntax scientists state the existence of syncretism in complex sentences, but they focus on the syncretism of semantic-syntactic relations between predicative parts. According to M. Kochergan, the main cause of syncretism in composite sentences is the combination of signs due to the imposition of values of predicative parts and ,values of relations" $"$. N. Ivanytska, exploring the two-member sentence in the Ukrainian language, notes the possibility of combining features not only in terms of content but also in terms of expression, as well as in terms of content and terms of expression at the same time ${ }^{5}$. L. Shytik comes to the same conclusion. The scholar proposes to single out among syncretic sentences those „,characterized by syncretism of form (structural variety), by syncretism of content (semantic variety), as well as syncretism of content and form at the same time" ${ }^{\text {.6 }}$. A. Zagnitko examines syncretism in formal, functional, and semantic aspects, in particular, he reveals three varieties of syntactic syncretism: formal-positional, semantic-positional, and functional-positional syncretism, but at the same time emphasizes that syncretic aspects can be combined ${ }^{7}$. Our analysis of complex sentences completely confirms this interpretation. Therefore, we consider it more convenient to describe the synchronous transitivity between complex sentences and sentences of other types - compound ones,

${ }^{4}$ Кочерган М. П. Синкретизм. Українська мова : Енциклопедія / редкол. : В. М. Русанівський, О. О. Тараненко, М. П. Зяблюк та ін. Київ : Вид-во “Укр. енцикл.” ім. М. П. Бажана, 2000. С. 539.

5 Іваницька Н. Л. Двоскладне речення в українській мові : підруч. Київ : Вища школа, 1986. С. 71.

${ }^{6}$ Шитик Л. В. Явища синхронної перехідності в системі складного речення. Украӥнська філологія : теоретичні та методичні аспекти вивчення : зб. праць наук.-практ. читань до 80-річчя Г. Р. Передрій. Черкаси : Брама-Україна, 2005. C. 217.

7 Загнітко А. П. Теорія сучасного синтаксису. Донецьк : ДонНУ, 2007. C. $245,247,249$. 
simple sentences, complicated with homogeneous elements, inserted constructions and additional predicative constructions, the transitivity between individual formal-syntactic types of complex sentences, and the transitivity within one formal-syntactic type of complex sentences.

\section{Syncretic structures with signs of complex sentences and sentences of other types}

The factual material examined makes it possible to ascertain the presence of transitional structures between complex and compound, complex and simple sentences with inserted structures.

\subsection{Syncretic complex - compound and compound - complex sentences}

I. Vykhovanets considers only the constructions with connectors тобто, себто, иебто, that express explanatory relations between parts as a transitional type between complex and complex sentences. He substantiates this view as follows: "The fixed order of parts, the presence of the conjunction, specialized in the expression of explanatory relations, its attraction to the second predicative part, similarity of the first predicative part to the principal one, and semantic conditionality of the second part converge the explanatory composite sentences with complex constructions and bring the explanatory part closer to the subordinate one. However, semantic parallelism, characteristic of explanatory composite sentences and formally syntactic and semantically syntactic similarity of predicative parts, lead to the fact that these composite sentences are considered to be compound ones. Therefore, explanatory composite sentences are neither complex nor compound"8. Revision of established concepts of connectors has led to the fact that in recent studies, in addition to the traditionally revealed coordinate and subordinate connectors, scholars began to consider transitional groups connectors of coordination-subordination and connectors of subordination-coordination ${ }^{9}$. This gives grounds to distinguish two types

${ }^{8}$ Вихованець I. Р. Граматика української мови. Синтаксис. Київ : Либідь, 1993. С. 345.

9 Городенська К. Сполучники української літературної мови. Київ : Видавничий дім Дмитра Бураго, 2010. С. 38-45; Кадочнікова О. Засоби зв'язку складників поліпредикативних сполучникових одиниць 3 пояснювальними відношеннями. Мовознавчий вісник. 2011. Вип. 12-13. С. 174. 
of transitional constructions between complex and compound sentences, which we will call complex-compound and compound-complex sentences.

Complex-compound sentences form the connectors of subordination-coordination. These sentences are at the same time signs of grammatical inequality and equality, and between their predicative parts, a syncretic subordinate-coordinate relationship is established ${ }^{10}$. To the connectors of subordination-coordination K. Horodenska includes explanatory connectors a саме, зокрема, надто, наприклад, насамперед, особливо, отже, передусім, приміром, такі як, як ось, $я \kappa-о m$, connectors of time and comparison тимчасом як, тодi $я{ }^{11}$, connector of condition and comparison mоді як. Supporting this view in general, we dare make some clarifications. In particular, according to our observations, connectors тоді як, тимчасом як may also express concessive-comparative value, cf .: Проте кожну 3 наведених концепцій зорієнтовано на частину вживань дієприкметника, тоді як він у граматичній системі сучасної украӥнської літературної мови виразно розчленовується на прикметникові цे дієслівні утворення (I. Vyhovanets) - Проте кожну з наведених конщепцій зорієнтовано на частину вживань дієприкметника, хоч він у граматичній системі сучасної украӥнської літературної мови виразно розчленовується на прикметникові й дієслівні утворення; Дуже багато місия тут займав тодішній марксистсько-ленінський "Закон Божий” (соиеківські дисципліни, до того ж трактовані в догматично-марксистському дусі), тимчасом як спеціальні (лінгвістичні) дисципліни викладалися в дуже спримітизованому вигляді... (Movoznavstvo, 2010, № 4-5) - Дуже багато місия тут займав тодішній марксистсько-ленінський “Закон Божий” (сочеківські дисципліни, до того ж трактовані в догматичномарксистському дусі), хоч спеціальні (лінгвістичні) дисципліни викладалися в дуже спримітизованому вигляді. In addition, we consider it advisable to add to subordinate-coordinate connectors correlatives якщо... то, коли... то, that convey a conditionalcomparative value, as well as correlatives хоч... хоч, чи то... чи то, чи.. чи, хоч.. хоч.. а, чи то.. чи то.. а, чи.. чи.. а, хоч.. хоч...

10 Городенська К. Сполучники української літературної мови. Київ : Видавничий дім Дмитра Бураго, 2010. С. 12.

${ }^{11}$ Ibid. P. 42-45. 
але, чи то... чи то... але, чи... чи... але, хоч... хоч... однак, чи то... чи то... однак, чи... чи... однак, хоч... хоч... одначе, чи то... чи то... одначе, чи... чи... одначе, хоч... хоч... та, чи то... чи то... та, чи... $ч u \ldots m a$, that express concessive-disjunctive meaning. K. Horodenska presents the first three conjunctions in the sentences Хоч іде дощ, хоч надворі хурделиия, листоноша вчасно принесе газету; Чи то спекотно надворі, чи то холодно, селяни зрання до пізньої ночі працюють на своїх городах; Скажи-но, Тріско, як ие ти вмудряєшся: Чи шторм, чи штиль, - ти зверху все тримаєшся (Yu. Krugliak) as conjunctions of coordination-subordination, without naming other connectors ${ }^{12}$. However, in our opinion, all of the above connectors should be ranked subordinate-coordinate ones. In connection with this, we single out the following semantic-syntactic types of complex-compound sentences: explanatory, of time and comparison, of condition and comparison, of concession and comparison and disjunctive-concessive.

Between the predicative parts of explanatory complex-compound sentences, there are explanatory semantic-syntactic relations, which are based on proper-semantic relations of identity as the relation of the general and the concrete, of the whole and the part. K. Horodenska divides explanatory connectors into explanatory-emphasizing (зокрема, зосібна, як-от, як ось, наприклад, приміром, такі як), explanatoryand-clearing out (a саме, отже) and accentuating-emphasizing (особливо, насамперед, передусім, надто) $)^{13}$, on the basis of which complex-compound sentences are divided into three varieties: 1) explanatory-emphasizing: Діти індиго від народження мають особливі здібності, наприклад вони можуть бачити енергетичне поле людини... (Ukraina Moloda, February 1, 2006); Прийменники можуть поєднуватися з декількома відмінками, приміром прийменник з сполучається з трьома відмінками - родовим, знахідним і орудним (I. Vyhovanets); 2) explanatory-clearing out: Щодо долі староукраїнської мови у Гетьманщині конче потрібне уточнення, a саме: поступово позбуваючися полонізмів $i$ зближуючись із народною мовою, ия мова у разі збереження української (навіть обмеженої) державності $i$ дальшого

${ }^{12}$ Городенська К. Граматичний словник української мови : Сполучники / Катерина Городенська. Херсон : Вид-во ХДУ, 2007. С. 256, 273-274, 277.

Ibid. P. 5; Городенська К. Сполучники української літературної мови. Київ : Видавничий дім Дмитра Бураго, 2010. С. 43. 
використання згаданої мови як офіиійної мала б усі підстави розвинутися з часом у повноцінну й багатофункціональну літературну мову (O. Tkachenko); 3) accentuating-emphasizing: ...відновлення статусу України як учасника американської Генералізованої системи преференцій найбільше посприяло українському експорту в США, передусім воно дає змогу ввозити $з$ України до США на безмитній основі більще трьох тисяч найменувань товарів (Ukraina Moloda, January 26, 2006); Вid підвищення цін на продукти харчування страждають сочіально не захищені верстви населення, насамперед потерпають пенсіонери й інваліди (Holos Ukrainy, November 11, 2005).

Compex-compound sentences of time and comparison form connectors тоді як, тимчасом як and specific lexical-semantic content of predicative parts. Like complex sentences of time, the constructions under consideration convey the simultaneous flow of two parallel phenomena, situations, actions, that is, they have an appeal to a temporal feature. But the lexical-semantic content of the predicative parts accentuates not only the simultaneity of the two realities, but also the difference between them, although the degree of dissimilarity may be different ${ }^{14}$, therefore, the situations conveyed in these sentences compare what is characteristic of compound sentences of comparison: Сполучники незалежні від поєднуваних частин у межах складного речення, тоді як прийменники тісно пов'язані з відмінковими закінченнями (К. Horodenska); Тоді як вони приймали присягу, інші ще збиралися з речами на призовних пунктах (Ukraina Moloda, Мау 30, 2006); Всі ичі обставини, гадаю, роблять цүілком виправданий акиент на слові “нова” в означенні украӥнської поезї, а не на слові “молода”: “молодою” іï можна назвати лише дуже умовно, тимчасом як “новою” вона є в багатьох відношеннях... (M. Ryabchuk). In addition to the above, subordinate-coordinate sentences of time and comparison fix the conjunction $y$ той час $я \kappa$, which usually expresses temporal semantic-syntactic relations, but under the corresponding lexico-semantic load of the predicative parts acts as the equivalent of temporal-comparative conjunctions moдi $я \kappa$, тимчасом як: У той час як жінка поралася по господарству, Андрій вештався по селу, шукаючи собі на голову клопотів

14 Шувалова С.А. Смысловые отношения в сложном предложении и способы их выражения. Москва : Изд-во Моск. ун-та, 1990. С. 136. 
(P. Punch). However, this connector is of loan nature and, according to K. Horodenska, since the 90's of the XX century it has been gradually revealing a tendency for a narrower use, for it being replaced by Ukrainian connectors тоді як, тимчасом як ${ }^{15}$.

Complex-compound sentences of condition and comparison form correlatives тоді як, якщио... то, коли... то аnd the appropriate lexicalsemantic content of predicative parts: Приблизно стільки ж [525 доларів] наймачам доводиться щомісяия викладати за звичайну трикімнатну на околиці, тоді як у иентрі оренда трикімнатної квартири тепер коштуе 843 долари (Zaporiz'ka Pravda, January 15, 2011); Якщчо раніше у Кіровській школі навчалося до трьохсот дітей, то зараз - 90 (Zaporiz'ka Pravda, April 7, 2009); Коли й справді на когось проливалися небесні дари, то їй судилися хіба щзо сльози (P. Zahrebelny).

Complex-compound sentences of concession and comparison, as well as those of time and comparison, form connectors тоді як, тимчасом $я \kappa$ and a specific lexico-semantic content of its parts: На думку М. Возняка, "Пораду" написано відразу після укладення унії, тоді як І. Франко датує ї̈ 1608 роком - після відвідин братчиків у Львові (Ukrains'ka Mova, 2010, № 4); Росіянка Н. Кузякіна усвідомила ие (the difference between the notions "national" and "nationalistic" $\mathrm{R}$. Kh.) в далекі 60-ті, тимчасом як значна частина украӥнців живе і нині у викривленому колі ичих понять (Dyvoslovo, 2008, № 9).

Disjunctive-concessive complex-compound sentences have a specific formal-syntactic and semantic-syntactic organization. The fact is that they function in three-component complex sentences, in which two equal predicative parts are connected coordinatively (between these parts, there are disjunctive relations), at the same time, these two predicative parts relate to the third predicative part as a single whole and are connected to it subordinatively, on the basis of which there appear concessive relations: Хоч лле дощ, хоч мете завірюха, дівчина виходить з дому на ранкову прогулянку; Хоч ллє дощ, хоч мете завірюха, але дівчина виходить з дому на ранкову прогулянку. The concessive relations are the main ones in this kind of conglomerate, which gives grounds to consider such sentences to be complex-compound.

15 Городенська К. Сполучники української літературної мови. Київ : Видавничий дім Дмитра Бураго, 2010. С. 133-134. 
Compound-complex sentences form coordinate-subordinate connectors, to which $\mathrm{K}$. Horodenska enumerates adversative-concessive connectors a, але, однак, одначе, проте, зате, та, explanatoryidentifying connectors або, тобто, цебто, себто, чи, сиріч and connectors of comparison and conformity omже $\check{u}$, omже $i{ }^{16}$. Accordingly, there are three semantic types of sentences under consideration: 1) adversative-concessive: Короткі літні ночі, а ия була незвично довгою, здавалось - ніколи не кінчиться (O. Honchar); Для Заболотного на той час дипломатська його дорога вже була визначена, але додому він прибув ще в льотчицькій формі... (O. Honchar); Термін девіатологія не належить до загальновживаних чи навіть широковідомих у науці про мову, однак ми все ж вирішили ним послуговуватись, керуючись суто науковими міркуваннями, а не бажанням якомога “науковіше” назвати явище, достатньо відоме в лінгвістииі, вивчення якого має значну традицію (F. Batsevych); Найбільше цьього щзастя [foot-drilling], звичайно ж, перепадало Духновичу, проте й після помкомвзводової надбавки він не міг тримати свій язик на припоні... (O. Honchar); Навкруг рясні стоять сади, платани і каштани, та шелест верб у пам'яті не тане (M. Rylskyi); 2) explanatory-identifying: Для того щуоб об'єднати суто релятивні первинні $i$ частково релятивні вторинні сполучники, запропоновано кваліфікувати їх як словаморфеми, тобто ӥм надано слівно-морфемний статус (К. Horodenska); 3) of comparison and concordance: ...людина має спати, отэне й вона спить... (V. Stus).

\subsection{Syncretic constructions with signs of complex and simple sentences}

Defining the concept of ,embedded constructions”, I. Zhytar defines them as structural elements of sentences with extra-grammatical status, adding to the basic sentence some additional messages, running comments, definite clarifications, explanations, that are separated from the basic sentence in view of intonation and punctuation and do not

16 Городенська К. Сполучники української літературної мови. Київ : Видавничий дім Дмитра Бураго, 2010. С. 39, 41. 
transmit modal, evaluative, emotional, pragmatic information ${ }^{17}$. Embedded constructions can formally become like dependent predicative parts of complex sentences: Він одвернувся, жалкуючи, мабуть, щцо отак враз, без підготовки (хоча яку ж тут підготовку придумаєш?) почав цюю розповідь (I. Matsenko); Щоб венгерка не додала чого-небудь гострішого - адже від неї всього можна чекати! - майстер сам поспішив заговорити до Шелюженка, голосно вихваляючи перед ним своїх лісорубів (O. Honchar). Simple sentences with inserted constructions of this type differ from complex sentences most often in their punctuation: while in simple sentences with inserted constructions brackets are typical, dashes occurring less, in complex sentences commas prevail. The transitivity between complex sentences and simple sentences with inserted constructions occurs at the functional-semantic level. The dependent predicative parts singled out by commas, the content of which regarding the content of the main part is perceived as incidental, the one that expresses some additional message, comment, explanations, clarification, tend to the inserted structures. As a result, we observe a weakening of the syntactic connection inside the sentence between the predicative parts of complex sentences, the subordinate parts acquiring the ability to express self-contained objective content, which is a characteristic feature of inserted components ${ }^{18}$. I. Zhytar calls sentences with attributive semantics as commonly used ${ }^{19}$. The factual material examined by us also most often attests to the transitional types between simple sentences with inserted constructions and complex sentences with the adverbial subordinate parts of the nonvalence character of attributive semantics. In particular, the transition is found in complex sentences, in which the subordinate part explains the prop noun - proper name. Nouns - proper names clearly define the subject matter and therefore, for the most part, do not need to be specified by definitions, which leads to the perception of the information expressed in the subordinate part as additional to the main one,

17 Житар I. В. Структура та стилістичні функції вставлених конструкцій у науковому і публіцистичному стилях української літературної мови : автореф. дис. ... канд. філол. наук : 10.02.01. Київ, 2011. С. 5.

18 Загнітко А. П. Теоретична граматика української мови. Синтаксис. Донецьк : ДонНУ, 2001. С. 257.

19 Житар I. В. Структура та стилістичні функції вставлених конструкцій у науковому і публіцистичному стилях української літературної мови : автореф. дис. ... канд. філол. наук : 10.02.01. Київ, 2011. С. 7. 
transmitted in the principle part: Навіть Іванові, котрий раніме сотні разів прочовгав цей плацик, застеляло очі сірою імлою (Yu. Mushketyk); В другій половині дня Балабін, який не мав жодного зв 'язку ні з одною із дивізій $і$ не знав, де вони знаходяться, розіслав своїх зв'язківиів вияснити обстановку (H. Tiutiunnyk); Шовкун, який не знав ніякого Сергєєва $і$ зовсім туманно розумівся на "вєєрах", немало дивувався з иієї невгамовності свого командира (O. Honchar). Occasionally, the subordinate parts may acquire some features of insertion to prop nouns - common names: Я плив високо в небі над білими, ніби вирізьбленими з рафінаду, який я так любив у дитинстві, містами... (V. Drozd); Давні слов'яни через брак тропічних рослин замінили пальмові гілки, якими встеляли дорогу Господу, на вербові (Zaporiz'ka Pravda, January 15, 2011); У висновку, який за змістом і стилем, найочевидніше, належить О. Потебні, цікавими $\epsilon$ міркування про суть $i$ властивості людської творчості... (Dyvoslovo, 2005, № 12 ).

In addition to attributive semantics, according to I. Zhytar, the inserted sentences can have adverbial semantics of time, reason, condition, purpose, and concession ${ }^{20}$. The factual material examined by us gives grounds to distinguish transitional constructions with semantics:

1) of condition: Якщчо вірити Геродоту, то територія иьього державного утворення була досить великою $i$ мала форму рівностороннього чотирикутника... (О. Boiko); Обличчя Галини, коли розглядати кожну його частину, не було красивим (M. Stelmah);

2) spatial one: Одного разу в Бомбеї, де пізньої ночі приземлився наш літак і довелося в аеропорту перебути кілька годин, чекаючи подальшого рейсу, вийшли ми з товаришем глянути на незнайоме місто (О. Honchar); У місті, де з стількох вікон чути гру рояля, Данко на це не звернув би уваги, але тут, серед тиші сільського вечора, ия музика вражала (Iryna Vilde); Перед поїзкою в аеропорт, звідки мав відлітати на Чорний континент рятувати дітей, просив свого друга дитинства вітати Тернівщину, кожну стежку і кожну травинку, зорі вранішні і вечірні (Ya. Hoуаn);

20 Житар I. В. Структура та стилістичні функції вставлених конструкцій у науковому і публіцистичному стилях української літературної мови : автореф. дис. ... канд. філол. наук : 10.02.01. Київ, 2011. С. 7-8. 
3) of concession: Вже пізніше, згадуючи той час, ті останні воєнні й перші повоєнні літа, вона завжди дивувалася, як дивується й дотепер, хоча дивування того й не поспішає виставляти на люди, де в неї й таких, як вона, сили тоді бралися? (I. Matsenko).

The attraction of such subordinate parts to the inserted structures occurs most often when moving them (subordinate parts) into interposition. The weakening of the syntactic connection inside the sentence between the predicative parts of complex sentences, and consequently, the approximation of the subordinate part to the inserted structure, is also facilitated by the implication of one of the predicative parts: ...я, Хома Прищепа, маю таку душу-комірчину, в якій, коли пильніше придивитись, десь на покуті ікона висить, святими барвами мерехтить (Ye. Hutsalo) - Я, Хома Прищепа, маю таку душу-комірчину, в якій, коли пильніше придивитись, то можна побачити, що десь на покуті ікона висить, святими барвами мерехтить; Бо коли подумати, то нічого лихого вона не заподіяла... (Ye. Hutsalo) - Бо коли подумати, то зрозумієш, що нічого лихого вона не заподіяла.

Occasionally subordinate parts of the connective type with general substantive semantics acquire features of inserted constructions, which facilitates the move of such subordinate parts into interposition: Зрештою, щцо важливіше, маємо мотив постійного пошуку людиною власної сутності та психологічного зростання в собі себто перетворення людини на Людину (Ukrains'ka mova v serednyh shkolah, himnaziyah, litseyah, kolehiumah, 2010, № 11-12); І здивувало iï [місто] не багатоповерховими будинками, не асфальтом, мчо властиво міському пейзажу, а деревами (I. Matsenko).

\section{Syncretic constructions with signs of different formal and grammatical types of complex sentences}

The transitivity between different formal-grammatical types of complex sentences occurs either only in formal-grammatical or simultaneously in formal-grammatical and semantic-syntactic aspects. Syncretism of complex sentences in formal and grammatical terms is not widespread. We have found a synchronous transitivity between the complex sentences of comparison through pronouns that have symmetric and asymmetric structure. Such are the constructions in which the subordinate clause with comparative pronominal words той, такий in the main part are connected by the conjunction $щ_{\text {o, }}$, which is always used 
together with an anaphoric pronoun він (вона, воно, вони), used in a certain case form: Біля собору цього дня знову з 'явилися ті, щуо їм за висоту не платять (О. Honchar); Навіть на передовій, як відомо, є найпередовімі, ті, щуо їх висунуто вперед на саме вістря позиџій (O. Honchar); Серед очеретяного плетива стійко трималися кущі калини, проте годі було сказати, який із них той, що до нього торкалися Тимошеві руки (I. Matsenko); Затамувавши подих, слухали ми про бога та янголів, про чортів $i$ святих, про пекло $i$ рай-всю оту біблійну премудрість, щзо нею був напханий Микола (A. Dimarov); Зачитувалися тексти різними мовами - тими, ще належать і могутнім народам, тими, що їхні носї̈ не такі вже й відомі у світі (Dyvoslovo, 2004, № 10); Горять облиті мазутом корчомакуваті, такі, щзо їх і ліквідувати важко, так звані неліквідні верби... (O. Honchar). S. Lomakovich believes that in such sentences the subordinate part presents a compound means of communication, which is analogous to the conjunctive word, "it contains the conjunction $щ о$, the function of which is the formal subordination of the subordinate part to the principal one, and personal-demonstrative pronouns він, вона, воно, which are close in meaning to the comparative items moü, ma, me, which enable it to perform the function of identification" ${ }^{21}$. In our opinion, just as in complex sentences with subordinate parts containing adverbials of not predetermined valence that have the same means of communication, in the considered sentences the subordinate part is connected with the main one only by the conjunction $щ о$, and the anaphoric pronominal component in one of the case forms is an additional element that merely emphasizes the connection. Adding the subordinate part to the comparative word by means of a conjunction is characteristic of complex sentences of an asymmetrical structure. At the same time, anaphoric pronouns are considered to be comparative words or nouns modified by comparative words in the main part, and the units що з ним, щуо його etc., come into correlation with the connecting words який, котрий. In this we see certain features of the structures of symmetrical structure. Therefore, the above makes it possible to consider the described complex sentences into syncretic ones.

The material examined gives grounds to single out structures that can be interpreted as transitional between complex sentences with adverbial

21 Ломакович С. В. Займенниково-співвідносні конструкції в системі складнопідрядного речення української мови. Київ : НМК ВО, 1993. С. 29. 
valence not predetermined by substantively subordinate parts of attributive semantics, and connective complex sentences of substantive semantics. We treat their syncretism as purely formal, since in them the change of the formal type leads to a simple replacement, not to a symbiosis of semantic-syntactic relations: Використана пояснювальна модель не пропагується як єдино можлива, вона подається як варіант, щуо не виключає побудову інших споріднених чи принципово відмінних, але спрямованих до більш глибокого і детального висвітлення змісту психологічних феноменів (Osnovy psyholohii).

There is a more widespread transitivity between certain formalsyntactic types of complex sentences, which arises simultaneously in formal-syntactic and semantic-syntactic aspects.

The transitional type between sentences with valence predetermined and valence not predetermined adverbial subordinate parts are sentences with prop verbal nouns that retain the valence of the forming verb. Formal and grammatical syncretism are characteristic of such sentences. The subordinate part in them is at the same time predetermined by the valence characteristics of the prop verbal noun, which preserves the property of the source verb to open right-sided object position, and the morphological features of the reference wordnoun. At the same time, formal-grammatical syncretism leads to semantic-syntactic syncretism - these constructions combine object and attribute meaning: Існує думка, щцо XXI cm. стане віком кібернетики $i$ лінгвістики, у межах якої комунікативна лінгвістика відіграватиме провідну роль (F. Batsevitch); А мої люди привезли звістку, щцо у Мозирі й Турові на Білій Русі Януш Радзівіл вирізує селян, сотнями на палі садовить, вогню на поталу віддав села і міста (N. Rybak). However, it should be noted that the syncretism of formal structure and semantics in such sentences must necessarily support the content of the predicative parts, especially of the subordinate one, cf. Якби знаття, я б зарані заяву написав до вищзого командування, щцоб мене ні в льотчики, ні в моряки не брали, а тільки в піхоту (H. Tiutiunnik); Офічійною ж причиною розлучення в заяві, яку зірка подала до Верховного суду Лос-Анджелеса, Кардашян вказує стандартні “нездоланні протиріччя” (Ukraina Moloda, November 3, 2011). The semantics of the subordinate part of the first sentence maintains the object valence of the verbal noun заява (affidavit), so it is syncretic, the content of the subordinate part of the second sentence does not support such valence, so syncretism is not characteristic of it. 
Complex sentences with prop nouns like abovementioned ones have repeatedly attracted the attention of both Ukrainian and Russian syntaxists, but they have not formulated a unified interpretation so far. Some linguists view these constructions as complex explanatory sentences without any other shades of meaning ${ }^{22}$, others note the complication of the explanatory subordinate part by the attributive shade of the meaning and associate it with the morphological-syntactic nature of the noun ${ }^{23}$, still others consider them complex sentences with double meaning ${ }^{24}$. N. Formanovska explains the double meaning of these sentences by the fact that the noun in the main part requires its modifying definition, and in the subordinate part the conjunctions that give the sentence other shades of meaning may be found ${ }^{25}$. In our opinion, the syncretism of such constructions is determined not only by conjunctions and prop words, which may be the nouns of the deverbatives of particular semantic groups, but also to a large extent by the lexical content of the subordinate part. It is the content of the subordinate part that allows or does not allow a double meaning, and accordingly predetermines the choice of the connective: in syncretic sentences - the conjunction буцім, буцімто, мов, мовби, мовбито, немовбито, наче, начебто, неначе, неначебто, ніби, нібито, чи, що, щуб, як, and in the sentences with subordinate attributive parts of a nonvalent character connective words який, котрий and the conjunction, щщо combined with

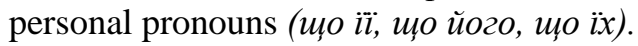

Semantic groups of nouns-deverbatives that can attach such syncretic subordinate parts have been identified. These are the nouns with the meaning of speech, message, perception and transmission of information (звістка, вість, заява, чутка, твердження, підтвердження, повідомлення, оголомення, інформачія, донос, запевнення, зауваження, роз'яснення, відповідь, пророцтво, попередження, обічянка, клятва, зізнання, натяк, суперечка, свідчення та ін.),

22 Бабайцева В. В., Максимов Л. Ю. Синтаксис. Пунктуация. Москва : Просвещение, 1987. С. 191-192; Русская грамматика. В 2-х т. Т. 2 : Синтаксис. Москва : Наука, 1982. С. 472.

${ }^{23}$ Валгина Н.С. Синтаксис современного русского языка. Москва : Высш. шк., 1978. С. 332.

${ }^{24}$ Формановская Н. И. Сложное предложение. Современный русский язык. В 2-х ч. Ч. 2 : Синтаксис / В. П. Вомперский и др. ; под ред. Д. Э. Розенталя. Москва : Высш. школа, 1979. С. 154-238. С. 198-199.

${ }^{25}$ Ibid. 
thinking, mental activity (думка, гадка, міркування, усвідомлення, згадка, знання, знаття, довідка, здогадка, переконання, повчання, пояснення, передбачення, рішення, уявлення, мрія та ін.), will expression and motivation (вимога, наказ, постанова, прохання та ін.), perception, sensation (чутка, передчуття та ін.), сподівання, віри (сподівання, надія, віра, повір'я та ін.), inner state, feelings (побоювання, боязнь, переживання та ін.): Тим часом поміж стамбульських иеехв, які ще тільки наближалися десь до АтМейдану, виникли суперечки, кому першим проходити перед султаном (P. Zahrebel'nyy); У сучасній історичній та народознавчій літературі існує твердження, щцо трипільијі - прямі предки українського народу (О. Bоуko); Дослідники творчості Тичини одностайно доходили думки, щцо поет у “Золотому гомоні" пророче передбачив трагічні події громадянської війни, коли внаслідок класового протистояння нищилась ідея національного єднання заради відродження незалежної України (Dyvoslovo, 2004, № 2); Концепція західної корпоративної стратегії трунтується на переконанні, щзо планування дає змогу компанії уникнути помилок $i$ сприяе оптимальному прийняттю управлінських рішень (H. Kindrats'ka); Серед місиевих людей ходили чутки, щчо моряків фашисти розстрілювали на скелях $i$ звідти - навіть ще живих кидали в море (О. Honchar); Існувало повір'я, щц верба охороняє людей від підступності злих духів, охороняе худобу $і$ посіви від різних нещасть (Zaporiz'ka pravda, April 11, 2009); Мені здається, що у нього є побоювання, що він нічого вже, може, не напише в своєму житті видатного, щи він розучивсь, розгубив, забув (O. Dovzhenko). Syntaxists point out that some nouns that do not have word-forming links to verbs may be involved in the formation of certain syncretic complex sentences: слово, телеграма, депеша, ідея, факт, приклад, історія, версія, гіпотеза, закон, правило, теорія, висновок, свідомість еtс. I. Kruchinina, considering such nouns in the Russian language, expressed her opinion on their synonymous relations with verb constructions $^{26}$. This statement needs certain clarification. In our opinion, the analysed nouns have rather certain semantic parallels with verbal units, rather than synonymous ones; as the result, the verbs acquire

26 Кручинина И. Н. Сложноподчиненные предложения нерасчлененной структуры. Русская грамматика. В 2-х т. T. 2 : Синтаксис. Москва: Наука, 1982. C. 472. 
valence properties: Мені важко од свідомості, щцо "Украӥна в огні" ие правда (О. Довженко); Прочитавщи нариси, присвячені фразеологізмам, доходиш висновку, щьо родовід українського народу снується від першоз'яви людини на тому обширі, де дотепер етнічні українські землі (Dyvoslovo, 2004, № 10); За законом, щчо гріх притягує гріх, вона, “розбишащька дочка”, сходиться в любові саме з Чіпкою... (Dyvoslovo, 2004, № 9).

Transitional types are also observed between complex sentences with adverbial valence-predetermined and modifying the principle part subordinate parts. In the analysed factual material, the constructions with syncretic object-cause, object-time, and object-target semantic-syntactic relations between the predictive parts were identified.

Syncretic object-causal complex sentences form separate verbs and predicates of the internal state, the predicative parts are joined by the conjunction that що: I плакала Марія Магдалина, щцо не подав ніхто йому руки (L. Kostenko); Певне, і йому трохи не по собі, мцо вони так далеко зайшли в море... (O. Honchar); Левко жалкував, щцо так мало поговорив з матір'ю після приїзу (O. Savchuk).

Object-time semantic-syntactic relations arise in complex sentences with prop verbs of internal state, feelings, verbs of hope, belief, surprise, set phrases with the same meanings, valence characteristics of which imply the expansion of the object, and with connectives коли, доки, допоки - which express the meaning of time: ...молоді солдати в захваті були, коли вона вчепіриться котромусь у вухо $і$ потягає, полоскоче своїми рученятами (О. Honchar); I жждатиму, допоки знов зійде моя душа, безсмертна $і$ весела (I. Zhylenko); Перед світлофором довелось перечікувати, доки проповзе трамвай (O. Honchar); Він був середній на зріст $і$ завжди дивувався, коли велетні-сини оступали його, мов бір (Yu. Yanovs'kyy).

Syncretic object-purpose semantic-syntactic relations convey complex sentences with prop verbs of speech and the conjunction щиб: Хто запалив світло в соборі душі і помолився, щцоб воно через роки спалахнуло сяйливо $i$ навколо нього перед свойм прийдешнім воскресінням об'єдналась Україна? (Yа. Hоуап).

The transitivity between complex contractual sentences with adverb valence-nonpredetermined and modifying the main part subordinate parts can be observed rarely. In such syncretic sentences attribute-time relations can be revealed: Україно! Тебе я терпіти не можу, Я тебе ненавиджу чуттями всіма, Коли ти примітивна ци на лубок похожа, Коли думки у тебе на лобі нема (V. Symonenko), as well as 
relations of attribute-cause: Калина кликала наполегливо ци мов аж сміялася з радості, щцо така дорідна та пригожа (I. Matsenko).

The transitivity between complex sentences with adverbial valencenonpredetermined subordinate parts and the ones modifying the main part through mediator has also been traced. Syncretic attributive-time, attributive-conditional and semantic-spatial relations are represented in such sentences.

Syncretic relations of attribute-time occur when in the main clause the nouns or semantically indivisible conjunctions denoting time are use as prop words, and the subordinate clause is joined by the connective коли: Навіть y темну, осінню ніч, коли крута, піднята степовими вітрами хвиля запліскує аж на палубу, не икодує він, щзо обрав собі цей нелегкий фах (O. Honchar); В наступну хвилину, коли він удруге зиркнув на неї, той погляд був уже зовсім інший... (V. Malyk); Свого часу, коли дітей народжувалося мало, дитячі дошкільні заклади не розформували, на їхній базі створили школи-дитсадки, як, наприклад, у мікрорайоні Дмитрівка (Zaporiz'ka pravda, April 7, 2009).

When in the main part such words as за умови, у разі, are used as prop words, and in the subordinate part we find conjunctions якщо, коли, between the predicative parts we reveal the syncretic attributiveconditional relations: У разі, якщо партія проходить до Верховної Ради, иі кошти їи повертають (Ukrayina moloda, 10 October, 2007); За умови, коли партія проходить до Верховної Ради, ияі кошти їй повертають.

Syncretic attributive-spatial relations occur in complex contract sentences, in the main parts of which nouns, functioning as verbal extensions or adverbs with spatial meaning are used, and the subordinate parts are joined by connectives де, куди, звідки: Малесенька зірочка, оточена суиільною темрявою, рухається в безмежному просторі, де немає ні землі, ні неба, тільки страшний морок (О. Honchar); Недумано, негадано забігла в глухомань, де сосни пахнуть ладаном в кадильнииях світань (L. Kostenko); Суперечка їхня відбувається неподалік веранди, на присадибній ділянці, де вони працюють обоє... (О. Honchar); Зустрічали потім його наші хлопці-приписники в літніх військових таборах у лісах за Ворсклою, куди тернівщан відповідного віку щоліта брано було в терчастини на військовий вишкіл (O. Honchar); Тому міцуно, нервово стиснувши Севера за руку, я разом з іншими втупила очі в сцену, в ї̈ лівий кут, звідки звичайно виходять артисти (Iryna Vil'de). 
A similar transitivity can be traced between the pronominal-related complex sentences and complex sentences with subordinate parts modifying the main part through a mediator.

In the case when in the main part the nouns to indicate the time intervals in combination with the indicative pronouns коли, доки, поки function as the prop words, in other words, in the main clause we have units like y той час, у ту хвилину, у ту мить, у той момент, у той день, у той рік, тим часом еtc., syncretic attributive-time relations emerge between the predicative parts: Саме в той час, коли я вже вирішив повернути назад, у коридорі почулися чиїсь енергійні кроки... (Yu. Zbanats'kyy); Та найбільшої яскравості $i$ теплоти досяг мій день у той час, коли я йшов на перший урок у шостий клас (Yu. Zbanatskyy); I ось у той момент, коли периий боєць загнав свій заступ у землю, тут, у степу під Каховкою, зародився Каховський плацдарм (О. Honchar); Тим часом, доки відбувалася церемонія вручення кубка, Оксана Терентіївна на борту машини пришпилила “блискавку”... (I. Matsenko).

If in the main part the prop words are раз, випадок in combination with the pronominal word той, and the conjunctions коли, якщо are used in the subordinate part, it is possible to speak of syncretic attributive-conditional relations between the predicative parts: Закрита система постає в тому разі, коли мова не дозволяє жодного розширення (A. Zahnitko); ...відношення в середині полісемантичного слова, особливості його організащії $і$ мовні засоби маніфестації окремих значень краще виявляються в тому разі, якщо аналізувати певну семантичну групу чи тип слів, де усі елементи групи є співмірними $і$ перебувають у чітких смислових і граматичних відноменнях (L. Lysychenko).

The transitional between the pronominal-related complex sentences of symmetric and asymmetric structure are constructions, in which the related pronominal word modi is present in the main part, and the subordinate part is connected by a conjunction коли, which permits its interpretation as both a connecting word with time semantics and a conditional conjunction. Accordingly, in the semantic-syntactic aspect, they are characterized by complex relations of time-condition: Мале тоді смішне, Коли воно мізерне, Коли себе поставить над усе (V. Symonenko); Людина може йменуватись людиною лише тоді, коли пал своєї душі віддає в ім'я спільної справи (Ye. Hutsalo); Заперечне значення лексем увиразнюється тоді, коли вони потрапляють у позицію реми (Ukrayins'ka mova, 2004, № 3). 
There are some cases of transitivity between complex sentences with adverbial valence-nonpredetermined subordinate parts and connective complex sentences; between the predicative parts of such constructions semantic-syntactic relations of attribute - result occur: А панські драгони бешкет учинили у селі, що замість хат тільки димарі стирчать серед садиб (N. Rybak).

Sometimes transitivity covers three formal-grammatical types. In particular, the analysed material gives reason to speak about the syncretism of complex sentences with such subordinate parts, as: the adverbial valence-nonpredetermined, nodyfying the main part directly or through the mediator, in the semantic-syntactic aspect; in such sentences we observe complex attribute-time-conditional relations: А вечорами, коли тихо, виходять посидіти на своїй історичній лавиі Іван та Вірунька (О. Honchar), with adverbial valencepredetermined and valence-nonpredetermined subordinate parts and the ones modifying the main part and complex object-attributepurpose relations: Степногірський селищний голова Ірина Кондратюк запропонувала внести зміни до Конституції України, щоб сільських $i$ селищних голів обирали на n'ять років, як і депутатів (Zaporiz'ka pravda, April 7, 2009).

\section{Syncretic constructions within one formal-grammatical type of complex sentences}

Only semantic-syntactic aspect of synchronous transitivity is fixed in some pronominal-relative complex sentences and constructions with adverbial subordinate parts, modifying the main part. In particular, pronominal-relation sentences can form syncretic substantive-attributive, object-cause, object-purpose and conditional-time, and in sentences with subjunctive adverbial parts, modifying the main part - conditional-time and cause-purpose semantic-syntactic relations.

Substantive-attributive meaning is represented in the pronominalrelative constructions of symmetric structure:

1) with a related pronominal word такий, a pronominal unity like хтось такий, все те, все інше, щзось таке, that projects the attributive semantics of the subordinate part, and the connective word щ̧o in different declensional forms, which is an expression of substantive semantics: I тут вона почула таке, чого ніколи не сподівалася не те що наяву, у сні почути (I. Matsenko); Багато бачили вони такого, щцо не забудуть $і$ потомки в віках (O. Dovzhenko); В зімулених 
плечах, в жалібницькій позі ї̈ було щцось таке, що пройняло Ягора (O. Honchar);

2) with related substantive pronoun той and connecting words який, котрий, чий: Султан неблимно дивився на ту, яку звав Весняною Трояндою і Повелителькою Віку, яку ще зовсім недавно ставив понад усе, без якої не міг дихати (P. Zahrebel'nyy); Вона одна з тих, котрі уособлюють свій час (Slovo i chas, 2009, № 10); Навіть mi, в чиїх душах живе поезія урбанізму, мріють хоч раз провести вихідний поза містом, з ночівлею на Скарбному (O. Honchar). In contrast to compound sentences with correlative pairs, той-хто, тойщ̧, in which the connecting words support the acquired substantive semantics of a given correlation word; in the analysed sentences the connecting words, on the contrary, support its primary attributive meaning, resulting in syncretic substantive-attributive relations.

The same meaning is possible in pronominal-relative constructions of an asymmetric structure with a related substantivized pronominal word таке: Уперше йому було на віку таке, щоб на його мову дівчина заломлювала брови (I. Bahryanyy).

Object-causal semantic-syntactic relations arise in the pronominalrelated complex sentences of a symmetric structure formed by the correlation word me in the genitive case with the preposition залежно від: Залежно від того, що взяте за орієнтир на небі, відрізняють сонячну $i$ зоряну добу (I. Klymyshyn, I. Kryachko). Prepositional-case forms залежно від + nоun in the genitive case, in simple sentences function as syntaxeme of causal semantics (expressing the meaning of reason). The causal conjunction залежно від того щя, has not been fixed so $\operatorname{far}^{27}$, therefore, we state that in unity залежно від того the pronoun retains its subject semantics, at the same time, in general, this unity conveys the meaning of cause and reason, which causes the syncretism of such complex sentences.

Object-purpose semantic-syntactic relations occur for the same reasons as object-cause ones. They are revealed in the complex pronominal-related sentences of an asymmetric structure formed by a semantically neutralized correlative word $m e$ in accusative case with the preposition $\mathrm{Ha}^{28}$ and the connecting words щзб, аби: Злагоджена

27 Городенська К. Граматичний словник української мови : Сполучники / Катерина Городенська. - Херсон : Вид-во ХДУ, 2007. 339 с.

28 Городенська К. Граматичний словник української мови : Сполучники / Катерина Городенська. - Херсон : Вид-во ХДУ, 2007. С. 17, 289. 
робота всіх служб санаторію дала змогу заощадити кошти на те, щоб у чудовому парку знову “ожили”, запраџювали фонтани... (Ukrayinske slovo, March 8-14, 2006).

Syncretic conditional-temporal relations are possible in cataphoric sentences of an asymmetric structure with a related pronominal word modi in the main clause and the conjunction якщо in the subordinate clause. In such sentences, the prop pronoun in the main part emphasizes the time meaning, and the conjunction of the subordinate clause - conditional one, resulting in a complex conditional-time relation: Занятття у спортикколі можна відновити лище тоді, якщо зробити капітальний ремонт примішення (Zaporiz'ka pravda, January 15, 2011).

The combination of conditional and time meanings is also found in complex sentences with subordinate parts, modifying the main part, in particular, in some sentences with conjunctions коли, як: Коли я бачу жінку в любові, у святості чекання, мені хочеться вклонитися ій! (P. Zahrebel'nyy); Навіть як зорі вмирають у ніч горобину, Пломінь душі осяває чертоги небес (B. Oliynyk). I. Slinko, N. Huyvanyuk, M. Kobylyanska indicate that the conditional shade of meaning is mostly revealed in sentences with the present tense ${ }^{29}$. This is also proved by the analysed material, moreover, a syncretic conditional-time meaning is possible in the sentences of past tense imperfective aspect, comp: Коли $я$ бачив жінку в любові, у святості чекання, мені хотілося вклонитися ї̈! Syncretic conditional-time relations are also inherent in complex sentences with conjunctions щъо... то, що не... то, що... так, що не... так, як тільки, як тільки... так, як тільки... то: Що підскочить, то впаде; Що не встане, так впаде; Як тільки візьме ніж у руки, поріжеться; Як тільки візьме ніж у руки, так поріжеться; Як тільки візьме ніж у руки, то поріжеться. The syncretism of semantic-syntactic relations in such sentences arises on the basis that their content acquires a generalized character, which promotes abstraction from a specific time of the action performance; consequently, the meaning of the subordinate clause becomes a condition for the occurrence of the main clause action.

The analysed material gives grounds also to distinguish syncretic cause-purpose relations, which are characteristic of some constructions with subordinate parts, modifying the main sentence, connected by

${ }^{29}$ Слинько I. І., Гуйванюк Н. В., Кобилянська М. Ф. Синтаксис сучасної української мови : Проблемні питання. Київ : Вища школа, 1994. С. 525. 
connectors бо, щуоб, аби: ..вдова... почала діставати зі скрині полотно, бо вже скоро треба білити його (М. Стельмах); Марко, щьоб не нести всю дорогу торбину з харчами, примотузив ї бикові до рога (Н. Tyutyunnyk); Пріся плакала тихо, аби не зачув Явтушок... (V. Zemlyak).

\section{CONCLUSIONS}

Synchronous transitivity, that is, syncretism, is inherent in complex sentences just like in other language units. It is motivated by the fact that the atypical lexical-semantic form causes a discrepancy between the semantics of the structural scheme and the content of its specific speech expression, as the result, the structural scheme semantics is complicated by other types of formal-syntactic connections and semantic-syntax relations.

In a system of complex sentences, synchronous transitivity occurs between complex sentences and sentences of other types - complex, simple complicated, between separate formal-syntactic types of complex sentences and within one formal-syntactic type of complex sentences.

The transitional types between complex and compound sentences are represented by subordinate-coordinate constructions of explanatory, temporal-comparative, conditional-comparative, concessivecomparative, and concessive-disjunctive semantics, as well as coordinate-subordinate constructions of adversative-concessive, explanatory-identifying, and comparative-relevance semantics.

The synchronous transitivity between complex sentences and simple sentences with insertion arises in case if the content of the subordinate part is given the character of an additional, side note. Factors contributing to the appearance of the insertion in the subordinate parts features are the expression of the prop noun by a proper name, the movement of the subordinate part into the interposition, and the implication of one of the complex sentence predicative parts. The tendency to the inserted constructions under the abovementioned conditions show complex sentences with attributive, conditional, spatial, concessive semantics and occasionally subordinate clauses of nominal semantics.

Syncretism between the various formal-grammatical types of complex sentences is presented in both formal-grammatical and semantic-syntactic aspects. Only formal-grammatical syncretism is represented by pronoun-relative complex sentences with correlative pronominal words той, такий, and the conjunction щ̧о, used together 
with anaphoric pronominal nouns він, вона, воно, вони, which show the signs of symmetric and asymmetric constructions, and some complex sentences with the conjunction $m o$, which exhibits the signs of complex sentences of a typical formal structure with adverbial valencenonpredetermined subordinate parts and attached complex sentences.

Symbiosis of formal and semantic syncretism is possible in some pronoun-relative complex sentences and sentences of a typical formal structure with adverbial, subordinate parts and the ones, modifying the main part directly and through the mediator. Most often, such synchronous transitivity cover two formal-grammatical types of complex sentences and exhibits a dual semantic-syntactic character, although three formal-grammatical types are rarely involved in syncretic relations; these complex sentences are characterized by triple semantic-syntactic relations.

Synchronous transitivity within one formal-grammatical type of complex sentences occurs only in the semantic-syntactic aspect. Transitive semantic-syntactic relations are peculiar to some pronounrelative constructions of symmetric and asymmetric structure, exhibiting complex substantive-attributive meaning, some complex sentences of asymmetric structure, which may have object-causal, object-purpose and conditional-time value as well as some constructions of a typical formal structure with causal parts, which are characterized by conditional-time and cause-purpose semantics.

\section{SUMMARY}

The article is devoted to the analysis of syncretic constructions with the signs of complex sentences. It is substantiated that syncretism is caused by a discrepancy between the semantics of the structural scheme of the construction and the content of its specific speech expression, resulting in transitional type constructions appearance. It is found out that in the system of complex sentences synchronous transitivity occurs between complex sentences and the sentences of other types compound, simple, complicated with homogeneous elements, additional predication and inserted constructions, between individual formalsyntactic types of complex sentences and within one formal-syntactic type of complex sentences. The author has characterised transition types between compound and complex sentences, represented by compoundcomplex and complex-compound constructions; between complex sentences and simple sentences, extended by insertion. It is stated that such transitivity is represented simultaneously in formal-grammatical 
and semantic-syntactic aspects of the sentence. It is established that within the complex sentences, syncretism is represented by three varieties - purely formal, purely semantic, symbiosis of formal and semantic.

\section{REFERENCES}

1. Бабайцева В. В., Максимов Л. Ю. Синтаксис. Пунктуация. Москва : Просвещение, 1987. 256 с.

2. Бабайцева В. В. Явления переходности в грамматике русского языка. Москва : Дрофа, 2000. 640 с.

3. Балли Ш. Общая лингвистика и вопросы французского языка / пер. с фр. Е. В. и Т. В. Вентцель. Москва : УРСС, 2001. 416 с.

4. Валгина Н.С. Синтаксис современного русского языка. Москва : Высш. шк., 1978. 439 с.

5. Вихованець I. Р. Граматика української мови. Синтаксис. Київ : Либідь, 1993. 368 с.

6. Городенська К. Граматичний словник української мови : Сполучники / Катерина Городенська. Херсон : Вид-во ХДУ, 2007. $340 \mathrm{c}$.

7. Городенська К. Сполучники української літературної мови. Київ : Видавничий дім Дмитра Бураго, 2010. 208 с.

8. Житар І. В. Структура та стилістичні функції вставлених конструкцій у науковому і публіцистичному стилях української літературної мови : автореф. дис. ... канд. філол. наук : 10.02.01. Київ, 2011.20 с.

9. Загнітко А.П. Теоретична граматика української мови. Синтаксис. Донецьк : ДонНУ, 2001. 662 с.

10.Загнітко А. П. Теорія сучасного синтаксису. Донецьк : ДонНУ, 2007. 294 с.

11.Іваницька Н. Л. Двоскладне речення в українській мові : підруч. Київ : Вища школа, 1986. 167 с.

12. Кадочнікова О. Засоби зв'язку складників поліпредикативних сполучникових одиниць 3 пояснювальними відношеннями. Мовознавчий вісник. 2011. Вип. 12-13. С. 173-177.

13. Кочерган М. П. Синкретизм. Украӥнська мова : Енииклопедія / редкол. : В. М. Русанівський, О. О. Тараненко, М. П. Зяблюк та ін. Київ : Вид-во “Укр. енцикл.” ім. М. П. Бажана, 2000. С. 539. 
14.Кручинина И. Н. Сложноподчиненные предложения нерасчлененной структуры. Русская грамматика. В 2-х т. T. 2 : Синтаксис. Москва : Наука, 1982. С. 467-539.

15. Ломакович С. В. Займенниково-співвідносні конструкції в системі складнопідрядного речення української мови. Київ : НМК BO, 1993. $59 \mathrm{c}$.

16. Слинько I. I., Гуйванюк Н. В., Кобилянська М. Ф. Синтаксис сучасної української мови : Проблемні питання. Київ : Вища школа, $1994.670 \mathrm{c}$.

17. Формановская Н. И. Сложное предложение. Современный русский язык. В 2-х ч. Ч.2 : Синтаксис / В. П. Вомперский и др. ; под ред. Д. Э. Розенталя. Москва : Высш. школа, 1979. С. 154-238.

18.Шитик Л.В. Явища синхронної перехідності в системі складного речення. Українська філологія : теоретичні та методичні аспекти вивчення : зб. прачь наук.-практ. читань до 80-річчя Г. Р. Передрій. Черкаси : Брама-Україна, 2005. С. 216-222.

19.Шувалова С. А. Смысловые отношения в сложном предложении и способы их выражения. Москва : Изд-во Моск. ун-та, 1990. $160 \mathrm{c.}$

\section{Information about the author:} Khrystianinova R. O.,

Doctor of Philological Sciences, Professor, Depute Head of the Ukrainian Language Department,

Zaporizhzhya National University 66-A, Zhukovsky str., Zaporizhzhya, 69063, Ukraine 